\title{
UKRAINIAN VOCAL TRANSLATIONS: TRADITIONS AND PERSPECTIVES
}

\author{
Andriy Bondarenko \\ Concertmaster; ORCID: 0000-0002-6856-991X; e-mail: bondareandre@gmail.com \\ Kyiv National University of Culture and Arts, Kyiv, Ukraine
}

\begin{abstract}
The article discusses the tradition of performing vocal classical music in Ukrainian translations. There is a long history as well as substantial renewed interest in vocal translations in Ukrainian artistic circles. However, the lack of theoretical underpinning substantiating the benefits of performing of vocal works in a language other than the language of the original work leads to the appearance of various myths that impede the creative initiative and, in general, slow down the development of Ukrainian language opera and vocal chamber music.

The aim of the work is to explore the tradition of Ukrainian vocal translations in the context of current trends in Ukrainian and international vocal art, to systematize the information about publications of such translations and their use in performing practice.

Methodology of the study includes descriptive and interpretive approaches, statistical analysis of the collected information, as well as the comparative analysis of similar phenomena in modern art.

The scientific novelty consists in comprehensive covering the issues of Ukrainian vocal translation functioning and systematization of the data submitted in different separate sources.

Conclusions: The revival of Ukrainian vocal translations is possible on the basis of a comprehensive approach that includes concert activities, vocal score publications, audio and video recording and distribution, collecting information about such artefacts from the past decades, and conducting scientific work. The appearance of individual projects aimed to revive this tradition could be viewed as a patriotic wave in the context of the general revival of Ukrainian culture and in the context of global trends for mastering its classical heritage and finding new interpretations.
\end{abstract}

Keywords: libretto; opera; vocal music; translation; Ukrainian

\section{Introduction}

After more than three hundred years under Russian dominance, Ukraine now is faced with multitude of problems related to the preservation and revival of its cultural heritage. Straightforward State directives to prohibit publications in the Ukrainian language - such as the Valueyv Circular or the Emsky Decree - as well as more implicit methods, such as banning some publications, limited government funding 
and persecutions of individual cultural figures, have contributed to the accumulation of existing problems.

The collapse of the USSR and formation of independent Ukraine only partially solved the problems of preserving national culture: although ideological bans have been lifted, a considerable part of Ukrainians remained under the influence of Russian culture. As a result, Ukrainian artistic phenomena find significantly diminished audience, which in turn, under a new market economy, substantially hinders the development of the Ukrainian art.

The art of vocal translation, or translation of lyrics that allows vocal works to be performed in a language different from the original language while preserving the intonation and rhythmic characteristics of the original work, is one of the most interesting artistic phenomena and an indicator of the development of a nation's musical culture. For example, Russian musicologist V. Cheshikhin (1905), in order to separate those phenomena that belong to the history of Russian opera from those that do not belong to it, classified them as follows: if a foreign opera - for example, an Italian opera - was performed in Russia in Italian, then it was an example in the history of Italian opera only. On the other hand, if it was performed in Russian translation, then it belonged to the history of Russian opera (p. 45).

The role of the Soviet authorities in the development of such art as vocal translation is not straightforward. On the one hand, the policy of "rooting" proclaimed in the USSR in the 1920s played a positive role in the revival of Ukrainian culture. This policy also positively affected theatrical life in Ukraine; in particular, in 1926 Radnarkom issued a decree providing for the implementation of Ukrainian-language productions in Ukrainian theatres. As a result, the history of Ukrainian translations has lots of bright pages. Until the end of the 1970s, in the Kyiv Opera, the provisions of this decree were in effect for every opera production, including operas by Russian composers; and until 1990, all operas by Western composers had to be performed in Ukrainian. On the other hand, the Soviet authorities preferred to make publications of opera and chamber vocal music scores exclusively in Russian translations, while languages of the rest of the Soviet Republics, including the Ukrainian SSR, were ignored. Therefore, with rare exceptions, Ukrainian translations of Western European or Russian vocal classical works were not published. In 2012, the aforementioned situation prompted the author of this paper to start a systematic work on restoration of the tradition of Ukrainian vocal translation. The name of the project is World Classics in Ukrainian (WCU).

\section{The review of recent research and publications}

One of the most important papers on issues pertaining to vocal translations belongs to $\mathrm{G}$. Hansburh (2001). The author argues that, from the librettology standpoint, the language of the audience has to be given the priority when choosing the language of a performance (Hanzburh, 2001, p.v81). At the same time, the researcher points out some "terrible gaps", such as the lack of translations of classical vocal works, the lack of published Ukrainian-language vocal translations, etc. Another influential publication was in the form of a discussion between Maksim Strikha and Anatoliy Mokrenko that appeared as series of publications in newspapers and popular science 
journals. M. Strikha (2011) regretted the refusal of the National Opera of Ukraine management to stage opera in Ukrainian, while A. Mokrenko (2011) argued in favour of performing operas in the original language, thus defending the choice of the management. We present the analysis of this discussion in our previous papers (Bondarenko, 2017).

More recently, issues of Ukrainian-language vocal translations were discussed by Zh. Zakrasniana (2017), T. Kablova and T. Kychenko (2017).

It is also important to mention the research on Italian opera translations into Romanian (Cosma, 2014) and on multilingual operas issues (Mateo, 2014). Although these works do not directly concern the Ukrainian vocal art, they are valuable for our understanding of general European cultural context.

\section{The purpose of the article}

The purpose of the current work is to explore features of the World Classics in Ukrainian project and its perspectives in context of current trends in vocal art worldwide and in Ukraine, in particular.

\section{Presentation of the main material}

In the modern world practice, two distinct traditions of performing foreign-language vocal music co-exist: one tradition is to use the original author's language and the other is to perform in the language of the audience. Both approaches have their merits, and it would be a mistake to consider any of them unacceptable or forbidden. On the contrary, world tendencies towards democratization, pluralism and tolerance to opposing points of view imply a performer's right to interpret musical works including opera in various ways. There are many examples where directors make significant adjustments to the author's score. In some cases, this may even involve changing the storyline itself or adding some noise effects to the original music.

Similarly, performing of an opera (as well as vocal chamber music) in translation implies certain modifications to the author's score: namely, it is a change in the subtexting of vocal parts. Other language, thus making understanding of the work by the target audience easier, replaces the text of the original language.

However, if the aforementioned replacement of a scene, a set design, costumes, or other special effects, to certain degree, aim at modifying the original idea of opera's creators, the replacement of the original text with translation is meant to convey the original author's idea to those listeners who do not understand the language of the original work. In both cases, modifications are applied to make the work more accessible, more attractive to the audience; yet in the former case, it is due to external effects brought by the director, while in the latter case it is achieved by activating the features of the plot and characters that already exist in the original work.

Naturally, the performing of an opera in translation and bringing in other innovations do not exclude each other. On the contrary, director's interpretation can interact with the art of a translator, with the ultimate goal of achieving the most convincing aesthetic effect on the audience. 
As an example of such an interaction, we cite the 2019 Kyiv production of S. Rachmaninoff's Francesca da Rimini, Op.25, created by stage director Olexandr Spivakovskyi in Ukrainian translation by M. Strikha. Conditions of the chamber stage, limitations of the production budget, and some features of the plot - which included a frankly intimate scene between Francesca and Paolo, the scene that could not be hidden in artificial stage clouds, as was envisioned in the original libretto - prompted extraordinary solutions. The director chooses to use filaments to symbolize the emotional attachment of main characters. The final scene where Lanciotto in a fit of jealousy kills the lovers, was presented through the destruction of these symbolic filaments by the main character's sword, whereas in the original libretto, the moment of the killing also occurs in artificial stage clouds. Clearly, the solution chosen by the director was aimed at clarifying the key conflict of the opera, the classic conflict between passionate feelings and the duty that life circumstances call for.

The decision to perform this opera in translation rather than in the original language stems from the objective of enhancing the emotional effect of the opera. Although the audiences in Kyiv are fluent in Russian (which is the original language of Francesco's libretto), negative connotations that this language evokes in Ukrainian people, especially in connection with the Russian invasion into Crimea, Donetsk and Luhansk regions of the country would contribute to discomfort, above all for those in the audience, who have personally experienced tragic events, suffered from hostilities, lost friends or relatives. This factor is important for organizers of the production.

The question of which language to use in performing a particular vocal work is a "dilemma of losses" (this applies to both vocal chamber music and opera.) It is known that the poetic basis of vocal works has phonetic and semantic layers (Hanzburh, 2004, p. 82). If the original language is used to perform to a foreign audience, the semantic layer is mostly lost: the audience cannot fully understand and feel what is being sung. In the case of a translation, the phonetic layer is lost since the sounds usually correspond to different vocal letters than the ones intended by the composer.

According to $\mathrm{G}$. Hanzburh one should prefer keeping the semantic layer, especially in the case when the singer's native language is not the language of the original work and thus preserving the phonetic layer may become problematic anyway. Moreover, the preference should be given to the language of the audience also due to the nature of music perception. "The perception of music is an intimate process in which the melody and poetic text touch the deepest structures of the brain. If there is a chance that a word could enter those mysterious depths of the subconscious (following the penetrating melody), this word would be the word of one's mother tongue only", writes the researcher (Hanzburh, 2004, p. 82).

The history of vocal translations dates back several centuries. The very question of the historically first vocal translation remains open. Talking about the first well-known translations represented in the repertoire of modern opera theatres, such an example presents the opera by Christoph Willibald Gluck "Orpheus and Eurydice". Initially, this opera was written by the composer to an Italian libretto by Ranieri de' Calzabigi and was staged in Vienna on October 5, 1762. For the Paris premiere of August 2, 1774, the author invited French librettist Pierre-Louis Molina to prepare a French version of the 
libretto. In light of the innovative activity of Gluck and his librettist Calzabigi, clearly the semantic aspect of his opera seems to be more important to the composer than the phonetic one (Zakrasniana, 2017, p. 89).

The history of Ukrainian opera translations dates back to the first decade of the 20th century, probably, in relation to the theatre of Mykola Sadovsky, who in addition to dramatic performances was also involved in opera productions, including "The Bartered Bride" by B. Smetana, "Halka" by S. Moniuszko, "Cavalleria rusticana" by P. Mascagni, "Aeneida", "Drowned", "Christmas Night" by M. Lysenko, "Roxolian" by D. Sichynsky.

At the time of the Ukrainian State (1918), operas "Halka", "Faust", the aforementioned "The Bartered Bride", as well as "La Traviata" by G. Verdi, "Bohemia", "Madam Butterfly" by G. Puccini and "The Marmiad" by A. Dvořák were staged in Ukrainian translation (Gay-Nizhnik). Unfortunately, only a translation of Madame Butterfly, made by S. Charnetsky, has survived.

Since Soviet times, opera translations have remained one of the few areas where the Ukrainian creativity was allowed to exist. In 1926 Radnarkom issued a decree providing for the implementation of Ukrainian-language productions in Ukrainian theaters. The history of Ukrainian translations contains a lot of bright pages.

During 1930-1980, Kyiv and Lviv opera theatres used translations by M. Rylsky ("Seville Barber", “Carmen", "La Traviata", “Eugene Onegin"), M. Lukash ("Don Giovanni", "Lucia de Lammermoor"), Boris Ten ("Ball Masquerade" by Verdi, "Orpheus and Evridika" by Gluck), P. Tychyna (Lohengrin), I. Kocherga (Faust). In 1965, the Ukrainian translation by M. Bazhan was used in production of "Kateryna Izmailova" by D. Shostakovich, bringing the Shevchenko Prize to the author and the stage group.

Since the late 1970s, the golden age of Ukrainian-language opera turned into its decline. In 1978, "The Queen of Spade" by P. Tchaikovsky was commissioned in Kyiv for a "one-time-permit" performance in Russian. Since then, within a few years, all Russian-language operas have been performed in the original language.

Despite the fact that operas were staged at the Kyiv Opera and the soloists knew translations well, it was extremely difficult to pass on the tradition to their students. The fact is that, at the time, all the opera clavier of Western European authors was published only in Russian translations. Accordingly, the beginners or self-made performers (the amateur art was quite a common phenomena in the USSR) had a difficult choice between singing in the original language or in Russian translation.

This led to the situation where, among music lovers and even professional musicians, popular opera arias became recognizable in their Russian translations while remained unknown in Ukrainian translations.

In order to establish whether musicians are aware about the existence of Ukrainian vocal translations, the author of this work has repeatedly conducted the following experiment among participants of scientific and practical conferences. The author would read to his audience a few lines from a Ukrainian translation of a famous aria (for example, "Non più andrai, farfallone amoroso" from Mozart`s "The Marriage of Figaro"), he would inform the audience that the excerpt was from an aria. Upon noticing the confusion of the audience, the lines of the same aria were read in Russian translation. This time, the audience would enthusiastically recognize the piece. This 
experiment was conducted with the same result in different Ukrainian cities: even after 25 years of Ukrainian independence, Russian-language translations remain much more well-known to Ukrainians than Ukrainian translations.

There is only an approximate estimate of the to-date number of Ukrainian-language vocal translations. In fact, the complete catalogue of such works does not exist in Ukraine today. To establish the list, the following sources of information are available:

1) library catalogues;

2) archival material of Ukrainian opera and operetta theatres;

3) testimonies of individual vocalists, conductors, or music lovers who have performed or remember performances of operas in Ukrainian translations.

Let us consider these sources in more detail. The first and so far the only library catalogue of Ukrainian vocal translations is "Publication of World Vocal Music in Ukrainian Translations: Exhibition Catalogue" (Ishchenko \& Romanova, 2011).

This catalogue contains 159 published translations and 6 publications in newspapers and popular and scholarly journals. The distribution by genre is as follows: 21 publications of individual opera arias and libretto texts, 19 cantatas and oratorios, 117 songs and romances. The works represent 41 composers, 19 of them are Russian or Soviet composers and 22 are Western European authors. The greatest number of works belongs to J.S. Bach (19 parts from cantatas and oratorios), L. van Beethoven and F. Schubert (more than 20 songs, some of them have several variants of translations).

There is not a single complete vocal score of an opera among these publications: we were able to find only scores of individual opera arias or texts of libretto, sometimes only fragments of libretto were found. It should be noted that, as of today, virtually all of the 159 publications mentioned are bibliographic rarity; even such venerable collection as the Library of the National Music Academy of Ukraine does not have any copies of the publications mentioned. Therefore, these editions remain unknown to the vast majority of musicians, and vocalists, in particular.

The archival materials of Ukrainian theatres are stored partially in the Central State Archive-Museum of Literature and Arts (CSAMLA) of Ukraine. Unfortunately, this only applies to Kyiv theatres. The archive of the National Opera appears to be the most interesting for research. This archive is the only one containing opera libretto texts that were used in theatrical productions. This circumstance favourably distinguishes the National Opera from the National Operetta, where the management, for unknown reasons, chose not to keep the collection of operetta libretto translations.

We now briefly describe the collection of libretto translations of the Kyiv Opera. This collection is known in the CSAMLA as Fund No. 573, part 4 and includes 72 typewritten documents; 62 of them are opera libretto and 10 are ballet libretto. Some of the documents are variants of the same libretto (presumably changes or corrections were made during production), and thus there are only 47 unique documents among the 62 . Among these 47 operas, there are 15 Ukrainian, 15 Russian operas, and 17 operas by Western European authors.

Finally, the library of the Kyiv Opera preserved a number of vocal scores containing handwritten Ukrainian text. Although these scores are not publicly available, they were made accessible to scholars who were able to restore some texts of the translated opera 
librettos, including some of the operas performed in the Kyiv Opera that, for unknown reasons, were not represented in CSAMLA. For instance, only two libretto translations of P. Tchaikovsky's operas, "Eugene Onegin" and "Iolanta", could be found in CSAMLA. However, we learned about the production of at least another two Tchaikovsky's operas, "The Queen of Spades" and "Mazepa" (both translated by M. Rylsky): libretto translations for these two operas were found in the Opera library as vocal scores with handwritten Ukrainian lyrics.

However, the mere availability of translations does not ensure the revival of the tradition. The important question is whether the world classical music is actually being performed in Ukrainian translations nowadays. At least partially, this question can be answered by analyzing posters of theatres and concert halls throughout Ukraine.

The analysis shows that the practice of performing in Ukrainian translations has been partly renewed in at least three theatres in Kyiv - in the National Opera House, the Municipal Opera House, and the Opera Studio of the National Academy of Music as well as in some regional musical and drama theatres.

Due to its specialty, the National Operetta Theatre performs mainly operettas. The repertoire shown on the official site of the theatre includes over 10 operettas and musicals that are performed in Ukrainian translations, 4 of them are works by Imre Kalman. The repertoire of the theatre also includes two operas, "The Barber of Seville" by G. Rossini and "The Bell" by G. Donizetti, performed in Ukrainian. Some operettas here are also performed in Russian translation.

The National Operetta Theatre used to stage even more operas in Ukrainian translations in the past. Most notably, it is 1998 production of opera Porgy and Bess by J. Gershwin in translation by Bohdan Hnyd. Unfortunately, translations of these operas have not been published yet. In many cases, their future publication would require some restoration work.

The repertoire of the Kyiv Municipal Academic Opera and Ballet Theatre for Children and Youth includes mostly children's musicals and ballet. However, in recent years, it also started to stage one-act operas: recent production included such operas as "Bastien and Bastien" by W. A. Mozart, "Let Mama Live" and "Rita" by G. Donizetti. Larger operas, such as "Rigoletto" or "Bohemia", were performed here (as well as in the National Opera) in the original language.

In addition to big theatrical and concert establishments, there are notable artistic projects organized by groups of artists and customarily supported by non-government organizations.

Thanks to the multifaceted activity of Natalia Sviridenko, back in the 1990s, D. Bortniansky's opera "Le faucon" and "Alcide", J. B. Pergolesi's opera "La Serva Padrona", "Coffee Cantata" by J. S. Bach, and some chamber works, have been performed in new Ukrainian translations by M. Strikha.

The work of Natalia Sviridenko became inspiration for the World Classics in Ukrainian project that started in 2012. Some activities of this project were supported by Wikimedia Foundation, Inc.

A special feature of World Classics in Ukrainian (WCU) is that every piece performed within the framework of this project is required to be published in the Internet; the 
publication includes both the video or audio recording and the translated text. The purpose of such publications is to provide easy access for vocalists thus helping them in their quest for developing their own repertoire. Moreover, the lyrics, as far as possible, are published under free licenses, thus eliminating any copyright complications for those musicians who would like to use these publications for their creative work. The free license requirement is the essential feature of the Wikimedia project (the requirement similar to Wikisource or Wikipedia). The WCU activities include first performances of operas "Didona and Aeneas" by G. Purcell (translated into Ukrainian by Elena O'Lear), "Francesca da Rimini" by S. Rachmaninov (translated into Ukrainian by Maksim Strikha), and scenes from "The marriage of Figaro" by W. A. Mozart's based on translations by Ye. Drobiazko that were partially restored from handwritings found in CSAMLM.

Other activities of the WCU project include organizing chamber vocal music performances. In recent years, concerts included Polish songs by F. Chopin, the "Winterreise" lieder cycle and other songs by F. Schubert, songs by L. van Beethoven, R. Schumann, P. Tchaikovsky, S. Rachmaninov, and other authors. Most of these works were performed in Ukrainian for the first time.

In 2017, WCU organized its first vocal contest. The terms of the contest required performing pieces by Ukrainian and foreign authors, all works were to be performed in Ukrainian. Participants could choose to perform using existing texts but they were also encouraged to make their own translations. Owing to this contest, the Ukrainian translation treasury has been enriched by eight new translations, some made by the winners of the competition Daria Litovchenko, Anna Dankanich, and Alina Rybina.

During the 2010s, a stage director Yulia Zhuravkova conducted a number of interesting projects. Among the notable contributions are staging "Telephone" and "Martin's lie" operas by J. Menotti, as well as "Lucia de Lammermur" by G. Donizetti, the latter has been revived, after more than 20 years, in a Ukrainian translation by M. Lukash.

We also mention the 2004 Ukrainian performance of "St Matthew Passion" by J. S. Bach, translated by Tetiana Ostrovska. Unfortunately, it was the only performance of this work. It is noteworthy that the organizer of the performance is the American born conductor Roger McMurrin, whose native language is English. Mr. McMurrin has worked extensively with choirs in Presbyterian churches. An interesting feature of the Presbyterianism is that, similar to other Protestant movements, it employs parishioners' native language in the worship. The idea is that the worship is supposed to be fully understood by the parishioners. Hence, the text for works performed in the Protestant churches is written in respective parishioner's native languages. J. S. Bach who also worked in Protestant churches based most of his religious works, including the Passions, on German-language lyrics (or German-language translations of canonical texts). Thus, it was right and natural to use Ukrainian in the Kyiv performance of the Passions since this corresponded to both the intention of the composer himself and the spirit of the Protestantism.

The development and perspectives of the tradition of vocal translation also involve translators. As a matter of fact there is no complete catalogue of translators who 
have been engaged in vocal translation. Creating such a catalogue will be one future tasks. Here, we outline main directions of future research.

The history of Ukrainian vocal translation could be tentatively divided into three periods: pre-Soviet, Soviet and modern.

Unfortunately, the pre-Soviet period is the most difficult to study, as most translations of this era were destroyed by the Moscow authorities, often along with the translators themselves. Mykola Zerov, Lyudmila Starytska-Chernyakhivska, Dmytro Zahul and other poets became the victims of Stalin's terror. Their work in the field of vocal translations could be researched only partially. In particular, the only known opera translation of the pre-Soviet era is the translation by Stepan Chernetskyi of G. Puccini's opera Madama Butterfly, published in 1909 in Canada .

The Soviet period can be subdivided into the pre-war and post-war periods. The pre-war period is represented primarily by the work of Dmytro Revutskyi's poets group that was active in the 1920s during the period of the so-called indigenization. A valuable artefact of this era was a series of publications by "Knyhospilka" company in Kharkiv, which included scores by Western composers, most notably, L. van Beethoven and F. Schubert, with Ukrainian translations by Dmitry Revutsky, Maxim Rylsky, Mykola Zerov, and Oswald Burgardt. It is known that the group discontinued in the 1930s with the change in the party politics and the onset of mass repressions. M. Rylsky is the only one from this group of poets who managed to continue to work in the USSR in the post-war period.

The post-war period in the opera genre is represented by works of Mykola Bazhan, Maxim Rylsky, Yevhen Drobyazko, Boris Ten, Diodor Bobyr, Pavlo Tychyna, and Olexandr Vrataryov who worked in the operetta genre.

It would be particularly interesting to research the phenomenon of opera singers with literary gift. They translated opera librettos and performed their own translations as soloists. The list of such singers-translators includes Sergiy Kozak and Bogdan Gnyd who translated, respectively, "Otello" by G.Verdi and "Faust" by Ch. Gounod.

Finally, the modern generation of translators, besides the already mentioned Tatiana Ostrovskaya, Maxim Strykha, and Olena O'Lear include Valeriy Yakovchuk, who made many translations of chamber and opera music, and Julie Gershunska who translated F. Schubert's lieder cycles "Winterreise", "Die Schöne Müllerin", and R. Schumann's "Dichterliebe" and "Liederkreis", op. 39. Most of their works still awaits their first performance.

\section{Conclusions}

The Ukrainian cultural heritage includes a few hundreds translations of operas and vocal chamber music. Most of this works have not been published and therefore are not well-known nowadays. The revival of Ukrainian vocal translations is possible and requires comprehensive approach, including concert activities, vocal score publications, audio and video production and distribution, gathering information about such artefacts in the past decades and conducting scientific work. Due to lack of interest at the official State level, the only promising way is to engage individuals interested in the future of Ukrainian culture. 


\section{References}

Bondarenko, A. (2017). Problematyka vykorystannia ukrainskykh perekladiv vokalnoi klasyky v konteksti suchasnoi kultury [The Problems of Using Ukrainian Translations of Vocal Classics in the Context of Modern Culture]. Imidzh suchasnoho pedahoha, 5, 49-52 [in Ukrainian].

Cheshikhin, V. (1905). Istoriia russkoi opery: S 1674 po 1903 god [History of Russian opera: From 1674 to 1903] (2nd ed.). St. Petersburg: I. Iurgenson [in Russian].

Cosma, lu. (2014). The translation of Italian opera librettos in the nineteenth century: historical and cultural milestones. Translationes, 6(1), 78-92. https://doi.org/10.1515/tran-2015-0006 [in English].

Hanzburh, H. (2004). Vokalni pereklady libretnykh tekstiv yak element mystetskoi istorii Ukrainy [Vocal translations of libretto texts as an element of the art history of Ukraine]. In Ukrainska kultura: Problemy i perspektyvy (pp. 81-86). Kharkiv [in Ukrainian].

Ishchenko, Yu., \& Romanova, L. (Eds.) (2001). Vydannia svitovoi vokalnoi muzyky v ukrainskykh perekladakh: Kataloh vystavky [Publication of world vocal music in Ukrainian translations: Exhibition Catalog]. Kharkiv [in Ukrainian].

Kablova, T.B., \& Kychenko, T.O. (2017). Pereklady tekstiv svitovoi vokalnoi muzyky v konteksti suchasnoi kultury [Translations of vocal music texts in the context of contemporary culture]. Kultura i suchasnist, 2, 70-74 [in Ukrainian].

Mateo, M. (2014). Multilingualism in opera production, reception and translation. Linguistica Antverpiensia, New Series - Themes in Translation Studies, 13, 326-354 [in English].

Mokrenko, A. (2011, November 9). Opera: movnyi aspekt [Opera: linguistic aspect]. Den [in Ukrainian]. Strikha, M. (2011, September 8). Ukrainska mova v klasychnykh operakh - chy mozhlyve povernennia? [The Ukrainian language in classical operas - is it possible to return?] Day [in Ukrainian].

Zakrasniana, Zh. (2017). Operna klasyka v ukrainskykh perekladakh: stanovlennia, zanepad i vidrodzhennia tradytsii [Opera classics in Ukrainian translations: the formation, decline and revival of tradition]. In N.M. Krechko (Ed.), Muzychne mystetstvo Ukrainy: (Pytannia istorii, pytannia pedahohiky, pytannia vykonavstva, muzychne mystetstvo $v$ tvorchykh personaliiakh) [Music of Ukraine: (Questions of history, questions of pedagogy, questions of performance, musical art in creative personalities)] (pp. 87-95.). Kyiv: Lira-K Publishing [in Ukrainian].

\section{УКРАЇНСЬКІ ВОКАЛЬНІ ПЕРЕКЛАДИ: ТРАДИЦІї ТА ПЕРСПЕКТИВИ}

\section{Андрій Бондаренко}

концертмейстер; ORCID: 0000-0002-6856-991X; e-mail: bondareandre@gmail.com Київський національний університет культури і мистецтв, Київ, Україна

\section{Анотація}

Статтю присвячено традиції виконання вокальної музики в українських перекладах. Актуальність роботи пов'язана, з одного боку, із незгасним інтересом до вокальних перекладів в мистецькому середовищі, а з іншого - браком узагальненої інформації 
і теоретичних розробок, i, як наслідок - виникненням і побутуванням навіть в професійних середовищах різного роду міфів, що стримують творчу ініціативу митців та мистецьких колективів і загалом гальмують процес розвитку та оновлення української оперної та камерно-вокальної сцени.

Мета роботи - дослідити традицію українських вокальних перекладів у контексті сучасних тенденцій у вокальному мистецтві України та світу, систематизувати інформацію щодо видань таких перекладів та використання у виконавській практиці.

Методологія дослідження включає комплекс емпіричних та аналітичних методів збір та опис інформації, статистичний аналіз зібраної інформації, а також порівняльний аналіз з подібними явищами світового мистецького сьогодення.

Наукова новизна роботи полягає у комплексному висвітленні питань функціонування українських вокальних перекладів, систематизації даних, що представлені у джерелах розрізнено, вперше досліджується доробок сучасних українських майстрів вокального перекладу - В. Яковчука, Ю. Гершунської, Ю. Отрошенка, поглиблено теоретичні положення щодо основних вимог до вокального перекладу.

Висновки. Відродження українських вокальних перекладів можливе за умови комплексного підходу, що включає концертну діяльність, публікацію нот, відеозаписів, збір інформації про такі артефакти в минулі десятиліття та проведення наукової роботи. Появу окремих проектів, спрямованих на відродження такої традиції можна розглядати як в контексті патріотичної хвилі відродження української культури, так і в контексті загальносвітової тенденції до опанування класичною спадщиною і пошуку нових її інтерпретацій.

Ключові слова: лібрето; опера; вокальна музика; переклад; українська мова

\section{УКРАИНСКИЕ ВОКАЛЬНЫЕ ПЕРЕВОДЫ: ТРАДИЦИИ И ПЕРСПЕКТИВЫ}

\section{Андрей Бондаренко}

концертмейстер; ORCID: 0000-0002-6856-991X; e-mail: bondareandre@gmail.com

Киевский национальный университет культуры и искусств, Киев, Украина

\section{Аннотация}

Статья посвящена традиции исполнения вокальной музыки в украинских переводах. Актуальность работы связана, с одной стороны, с неугасающим интересом к вокальным переводам в художественной среде, а с другой - недостатком обобщенной информации и теоретических разработок, и, как следствие - возникновением и бытованием даже в профессиональных кругах разного рода мифов, которые сдерживают творческую инициативу людей искусства и творческих коллективов и в целом останавливают процесс развития и обновления украинской оперной и камерно-вокальной сцены.

Цель работы - исследовать традицию украинских вокальных переводов в контексте современных тенденций в вокальном искусстве Украины и мира, систематизировать информацию об издании таких переводов и использования в исполнительской практике. 
Методология исследования включает комплекс эмпирических и аналитических методов - сбор и описание информации, статистический анализ собранной информации, а также сравнительный анализ с подобными явлениями мирового художественного настоящего.

Научная новизна работы заключается в комплексном освещении вопросов функционирования украинских вокальных переводов, систематизации данных, представленных в источниках разрозненно, впервые исследуются труды современных украинских авторов вокального перевода - В. Яковчука, Ю. Гершунской, Ю. Отрошенка, углубленно теоретические положения относительно основных требований к вокальному переводу.

Выводы. Возрождение украинских вокальных переводов возможно при условии комплексного подхода, включающего концертную деятельность, публикации нот, видеозаписей, сбор информации о таких артефактах прошлых десятилетий и проведения научной работы. Появление отдельных проектов, направленных на возрождение такой традиции можно рассматривать как в контексте патриотической волны возрождения украинской культуры, так и в контексте общемировой тенденции к овладению классическим наследием и поиска новых его интерпретаций.

Ключевые слова: либретто; опера; вокальная музыка; перевод; украинский язык 